Pope praised for partial conciliation of science and religion

Quirin Schiermeier, Munich

Catholic researchers and bioethicists

have responded to the death of Pope John

Paul II with tributes to his efforts to

achieve reconciliation between faith and

science. And some are optimistic that his

successor will keep on the same path.

The Polish Pope had a strong personal interest in science and worked to reduce hostility between the scientific community and the Roman Catholic Church. Nonetheless, his strict rejection of abortion, embryonic stem-cell research and contraception, including the distribution of condoms to help contain AIDS, drew him into conflict with some scientists.

AIDS activist groups around the world still condemn John Paul's refusal to endorse the use of condoms. "It should not be forgotten that millions have died in Africa as a result of this theological rigidity," the London-based Independent newspaper said in an editorial.

However, John Paul frequently discussed scientific matters with such luminaries as Stephen Hawking, who is one of the 80 members of the Pontifical Academy of Sciences. And the Vatican received regular scientific advice (see Nature 432, 669; 2004).

"Many of us have witnessed a special feeling between the Pope and scientists," says Giuseppe Tanzella-Nitti, a theologian and astrophysicist at Rome's Pontifical University of the Holy Cross.

In 1980 at Cologne Cathedral, Germany, John Paul declared that there was "no contradiction" between faith and science. He said on several occasions that the concepts of the Big Bang and darwinian evolution were more than mere hypotheses. In 1992, he officially rehabilitated Galileo Galilei, conceding that the Church was wrong to arrest him.

More recently, the Vatican has stopped opposing modern techniques such as organ transplantation and genetic modification of animals.

Ludger Honnefelder, a Catholic theologian and philosopher at the Institute of Science and Ethics in Bonn, Germany, claims that John Paul helped religion and science to coexist. He notes that the next Pope will have to deal with issues such as the implications of genetic modification in humans. "We expect well-balanced answers from the Church to new ethical challenges," Honnefelder says, "just as we expect science not to think of itself as an almighty system."

IMAGE

UNAVAILABLE FOR COPYRIGHT REASONS

Water bombs: US submarines such as the Virginia are armed with W76 thermonuclear warheads.

\title{
Nuclear chiefs scotch story on frailty of ageing warheads
}

Geoff Brumfiel, Washington

Senior weapons scientists emphatically denied a report this week that the most important US nuclear warhead has a design fault that could make it unreliable.

The New York Times reported on 3 April that the W76, a thermonuclear warhead launched from submarines, has a flaw in the design of its casing that could cause it to explode with much less force than expected — or not at all.

Leading scientists who designed the warhead say that the accusations are completely unfounded, however, and that the report's sources weren't heavily engaged in the design project. "There is nothing wrong with the W76," says Harold Agnew, who was director of the Los Alamos National Laboratory in New Mexico when the lab designed and tested the warhead 30 years ago.

Exact numbers are classified, but armscontrol experts estimate that the W76 makes up almost one-third of the US stockpile of 10,000 warheads, as well as dominating the far smaller British nuclear arsenal. The warheads are compact and lethal: up to eight of them can sit in a single missile, each yielding an explosive force more than five times bigger than that of the bomb dropped on Hiroshima in 1945.

For about a year, some scientists have been expressing concern to government officials about the uranium case surrounding the warhead. The case is thin and light so that it can be carried on smaller, submarinelaunched missiles. The critics claim that it might fail when the fission trigger of the bomb detonates, meaning the bomb's powerful fusion fuel would not ignite.

The bombs are "at best unreliable and probably much worse”, Richard Morse, a retired plasma physicist from Los Alamos told the The New York Times. Morse did not respond to Nature's requests for an interview.

Other scientists familiar with the weapon dispute Morse's assertions. "I think he's wrong," says Richard Garwin, a prominent former hydrogen-bomb designer. Agnew, who was present at several tests of the W76, says that it never failed to detonate. He adds that six to nine warheads are carefully analysed every year to make sure that ageing will not affect their performance.

"We have looked into this concern extensively, and our best technical judgement is that it is simply wrong," Linton Brooks told the Senate on 4 April. Brooks is the administrator of the National Nuclear Security Administration, which oversees the US nuclear stockpile.

But Brooks added that his agency is now planning a study to create a more robust type of warhead. This might eventually replace weapons such as the W76, which was designed for minimum size and weight. He says that the Reliable Replacement Warhead programme will design weapons that have wider performance margins and can be more easily maintained without testing.

Arms-control experts are sceptical of the project, which will cost \$9 million in 2006 . "The existing stockpile is safe and reliable, and it is likely to be so for some time," says Daryl Kimball, executive director of the Arms Control Association in Washington, DC. "This programme seems unnecessary."

The replacement warhead programme would itself replace an 'advanced concepts' project, which has been criticized as a step toward development of new nuclear weapons (see Nature 428, 455; 2004). Opponents of new weapons note that doubts about the W76's reliability could boost political support for the replacement programme. 